Article

\title{
Antioxidative and Anticanceric Activities of Magnolia (Magnolia denudata) Flower Petal Extract Fermented by Pediococcus acidilactici KCCM 11614
}

\author{
Eun-Hye Park ${ }^{1}$, Hyun-Suk Kim ${ }^{1}$, Su Jin Eom ${ }^{1}$, Kee-Tae Kim ${ }^{2}$ and Hyun-Dong Paik ${ }^{1,2, *}$ \\ 1 Department of Food Science and Biotechnology of Animal Resources, Konkuk University, \\ Seoul 143-701, Korea; E-Mails: dms2353@naver.com (E.-H.P.); zmzm852@naver.com (H.-S.K.); \\ insomnia@daum.net (S.J.E.) \\ 2 Bio/Molecular Informatics Center, Konkuk University, Seoul 143-701, Korea; \\ E-Mail: richard44@hanmail.net \\ * Author to whom correspondence should be addressed; E-Mail: hdpaik@konkuk.ac.kr; \\ Tel.: +82-2-2049-6011; Fax: +82-2-455-3082.
}

Academic Editor: Maurizio Battino

Received: 14 May 2015 / Accepted: 30 June 2015 / Published: 3 July 2015

\begin{abstract}
In this study, the effects of magnolia (Magnolia (M.) denudata) extract fermentation in increasing the extract's antioxidative and anticancer activities were investigated. Magnolia was fermented by Pediococcus acidilactici KCCM 11614. The total phenolic content was determined by the Folin-Ciocalteu's method and the antioxidative effects by 1,1-diphenyl2-picrylhydrazy (DPPH) and ferric reducing ability of plasma (FRAP) assay. Anticancer activity against cancer and normal cells was determined using 3-[4,5-dimethylthiazol-2-yl]2,5-diphenyltetrazolium bromide (MTT). Total phenolic content during fermentation increased from 38.1 to $47.0 \mathrm{mg}$ gallic acid equivalent (GAE)/g of solid matter. The radical scavenging activity was $91.4 \%$ after $72 \mathrm{~h}$ fermentation. Fermented magnolia's antioxidative effect was threefold higher than that of the (non-fermented) control. Fermentation $(48 \mathrm{~h})$ increased anticanceric activity against AGS, LoVo, and MCF-7 cancer cells 1.29- to 1.36-fold compared with that of the control, but did not affect MRC-5 (normal) cells, suggesting that fermented magnolia could be used as a natural antioxidative and anticancer agent.
\end{abstract}

Keywords: flavonoid; Pediococcus acidilactici; Magnolia denudate; antioxidative effect; anticanceric activity 


\section{Introduction}

Magnolia (M.) denudata Desrousseaux (Magnoliaceae) is distributed mainly in East and Southeast Asia [1]. Flowering occurs in early spring before leaf flushing and the overall floral display is luxuriant because the individual flowers are large and numerous. $M$. denudata is a pharmacologically safe plant used in different commercially available forms such as teas; infusions; liquids; and capsules for human nutrition. Various biologically active compounds such as eudesmin; magnolin; epimagnoli; neolignans; lignans; phenyl propanoids; sesquiterpenes; and alkaloids have been isolated from Magnolia spp. [2]. Other researchers have reported that $M$. denudata is pharmacologically active against disease symptoms such as colds and chronic rhinitis [3]. However; some techniques are necessary to increase their activities for practical application although magnolia flower petals have various bio-functional effects.

Fermentation is used to enhance food quality features such as shelf life, nutritional value, and organoleptic properties [4]. Recently, fermentation has been applied to increase the production and extraction yields of bioactive compounds in the food and pharmaceutical industries [5]. For example, Jo et al. [6] reported that ginseng extract fermented by Aspergillus usamii had a greater anticanceric activity against HepG2, AGS, and DLD-1 cells than that of the non-fermented extract (NFM). Furthermore, Yoon et al. [7] showed that fermentation by Bacillus subtilis increased the antioxidant and anticanceric activities of black rice bran.

Pediococcus (P.) acidilactici is a representative lactic acid bacterium used to ferment dairy products [8]. Recently, several researchers have studied the bioconversion process of food components using this strain. Kaur et al. [9] for example, reported that fermentation by P. acidilactici could convert ferulic acid to vanillin and Michlmayr et al. [10] showed that two putative $P$. acidilactici rhamnosidase genes (ram and ram2) in combination with a bacterial $\beta$-glucosidase released the monoterpenes linalool and cis-linalool oxide from a wine extract under optimum conditions.

Oxidative stress is defined as an imbalance in the production of free radicals or reactive oxygen species (ROS) and the antioxidative reactions in the metabolic system of the living cell [11]. ROS, such as the superoxide anion $\left(\mathrm{O}_{2}{ }^{-}\right)$, hydrogen peroxide $\left(\mathrm{H}_{2} \mathrm{O}_{2}\right)$, the hydroxyl radical $\left(\mathrm{OH}^{\circ}\right)$, and organic peroxides, are produced in cells by the mitochondrial respiratory chain [12]. Ultimately, this imbalance leads to cell damage and that of important biomolecules, potentially compromising cell function [13]. Intracellular proteins and lipids are highly sensitive to oxidative attacks and oxidative modifications of these molecules can increase the risk of cancer [14]. Therefore, the purpose of this study was to ferment $M$. denudata by P. acidilactici KCCM 11614 to evaluate the antioxidative and anticancer effects of the fermented extract on various cancer cells for potential application in the food and pharmaceutical industry.

\section{Results and Discussion}

\subsection{Determination of the Total Polyphenol Content during Fermentation}

The stationary phase of the fermentation of the extract with $P$. acidilactici KCCM 11614 was reached after $24 \mathrm{~h}$ of culturing at $37^{\circ} \mathrm{C}$. The number of cells increased to $8.5 \pm 0.2$ colony-forming units (CFU)/mL of culture broth. The $\mathrm{pH}$ decreased rapidly from 6.5 to $3.7 \pm 0.1$, but did not change considerably after $48 \mathrm{~h}$ (Figure 1). The total acidity increased from $1.7 \%$ to $9.1 \% \pm 0.3 \%$ during fermentation. The $72 \mathrm{~h}$ fermentation time used in this study was based on these results. 

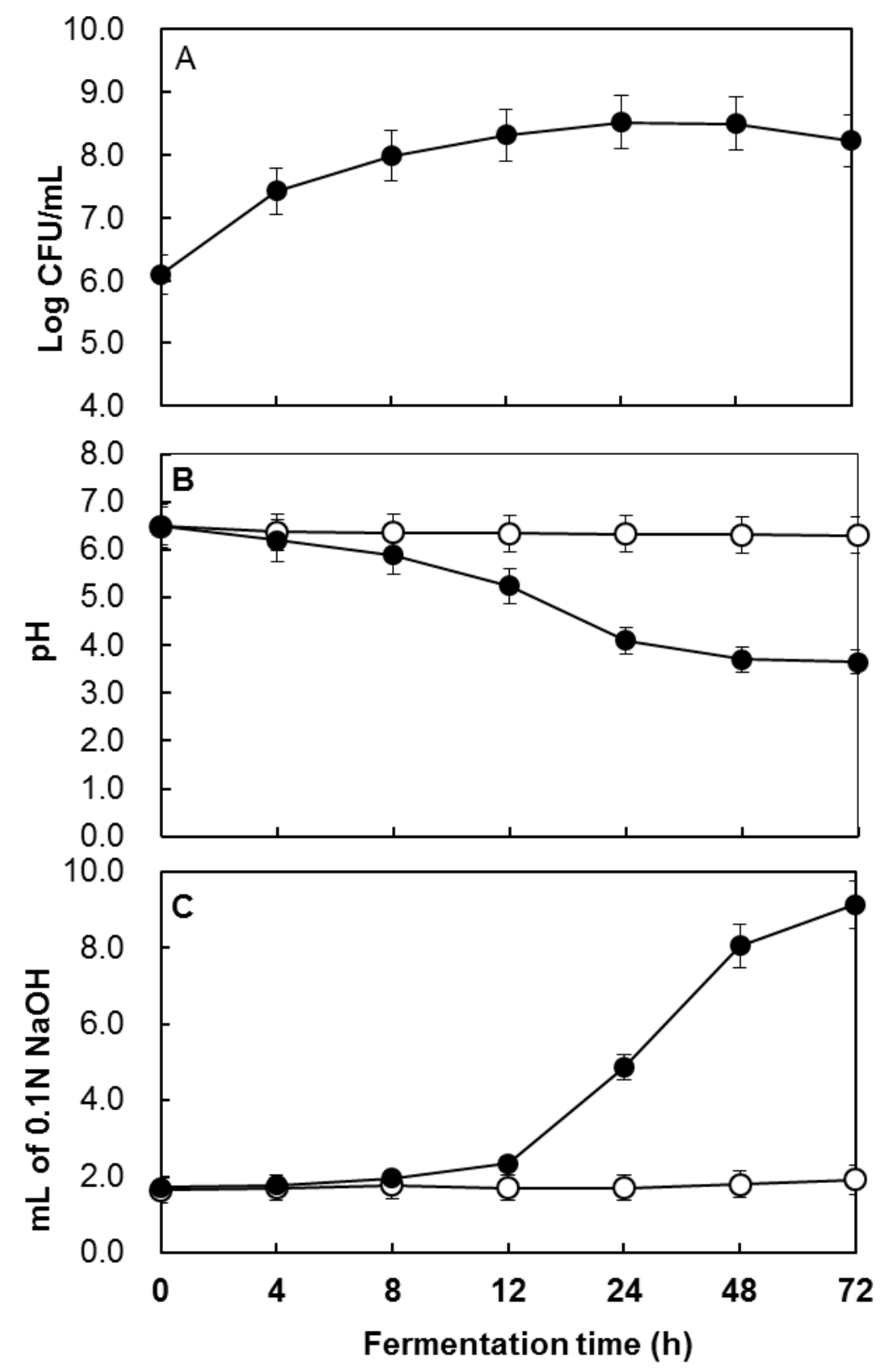

Figure 1. Growth (A); $\mathrm{pH}(\mathbf{B})$, and titrable acidity $(\mathbf{C})$ curves during the fermentation of M. denudata extract by P. acidilactici KCCM 11614 at $30{ }^{\circ} \mathrm{C}$ for $72 \mathrm{~h}$. $\circ$, Non fermented (control); •, Fermented.

It is known that the TPC is an important factor in evaluating the biofunctional activities of plant material [15]. As shown (in Table 1), the solid content had decreased from $29.2 \pm 0.4$ to $23.4 \pm 0.2 \mathrm{mg} / \mathrm{mL}$, and the TPC and total flavonoid content had increased from $38.1 \pm 0.4$ to $47.0 \pm 0.1 \mathrm{mg} / \mathrm{GAE} \mathrm{g}$ of solid and from $27.9 \pm 0.1$ to $39.6 \pm 0.2 \mathrm{mg}$ /quercetin $\mathrm{mL}$, respectively, during the $72 \mathrm{~h}$ fermentation. In fermentation of flower petal extract, differences in the polyphenol content can vary according to the resources [5] and microbial strains [16] used for fermentation. Duenas et al. [17] reported that microorganisms could hydrolyze complex polyphenols to other simpler and biologically more active compounds. Furthermore, Michlmayr et al. [10] reported that $P$. acidilactici produced two distinct glycosyl hydrolase ( $\alpha$-L-rhamnosidases). Therefore, in this study, it was presumed that $P$. acidilactici could effectuate the biotransformation of glycosylated aroma compounds to other components. 
Table 1. Solid and total phenolic content of M. denudata extract fermented by P. acidilactici KCCM 11614.

\begin{tabular}{cccc}
\hline Fermentation Time (h) & Solid Contents (mg/mL) & $\begin{array}{c}\text { Total Phenolic Contents } \\
\text { (mg GAE } \text { 1/g of Solid) }^{-}\end{array}$ & $\begin{array}{c}\text { Total Flavonoids } \\
\text { (mg Quercetin/mL) }\end{array}$ \\
\hline 0 & $29.2 \pm 0.4^{2}$ & $38.1 \pm 0.4$ & $27.9 \pm 0.1$ \\
12 & $26.5 \pm 0.2$ & $42.3 \pm 0.8$ & $31.3 \pm 0.1$ \\
24 & $26.0 \pm 0.1$ & $42.4 \pm 0.9$ & $33.8 \pm 0.2$ \\
48 & $24.5 \pm 0.1$ & $48.1 \pm 0.5$ & $38.1 \pm 0.1$ \\
72 & $23.4 \pm 0.2$ & $47.0 \pm 0.1$ & $39.6 \pm 0.2$ \\
\hline
\end{tabular}

${ }^{1}$ Gallic acid equivalent. ${ }^{2}$ Values are means \pm SD of triplicate experiments.

\subsection{Antioxidative Activity of Fermented Magnolia Extract}

To evaluate the antioxidative activity of magnolia fermented by P. acidilactici KCCM 11614, several different assays were used to determine the antioxidant activity rather than depending on a single assay, since each method has a different underlying mechanism. Therefore, the methodological limitations and the antioxidative results obtained may be different depending on the analysis method. In this study, the DPPH, $\beta$-carotene, and FRAP assay were used of which the results are shown (in Table 2).

Table 2. Antioxidative activities of $M$. denudata extract fermented by $P$. acidilactici KCCM 11614 as determined by the DPPH, $\beta$-carotene, and FRAP assay.

\begin{tabular}{|c|c|c|c|c|c|c|}
\hline \multirow{2}{*}{ Fermentation Time (h) } & \multicolumn{2}{|c|}{ DPPH Method (\%) } & \multicolumn{2}{|c|}{$\beta$-Carotene Method (\%) } & \multicolumn{2}{|c|}{ FRAP Assay ${ }^{1}$} \\
\hline & NFM $^{2}$ & FMPA $^{3}$ & NFM & FMPA & NFM & FMPA \\
\hline 0 & $80.7 \pm 3.1^{4, \mathrm{~d}}$ & $85.1 \pm 0.3^{\mathrm{b}, \mathrm{c}}$ & $84.5 \pm 2.4^{\mathrm{a}}$ & $80.7 \pm 3.1^{b}$ & $1.3 \pm 0.1^{\mathrm{a}}$ & $1.3 \pm 0.1^{\mathrm{a}}$ \\
\hline 24 & $82.3 \pm 1.4^{\mathrm{d}}$ & $91.5 \pm 0.4^{\mathrm{a}}$ & $84.0 \pm 1.1^{\mathrm{a}, \mathrm{b}}$ & $68.7 \pm 1.3^{\mathrm{c}}$ & $1.3 \pm 0.1^{b}$ & $1.2 \pm 0.1^{b}$ \\
\hline 48 & $86.0 \pm 0.8^{b}$ & $91.1 \pm 1.0^{\mathrm{a}}$ & $84.2 \pm 0.5^{\mathrm{a}}$ & $60.4 \pm 7.1^{\mathrm{d}}$ & $1.3 \pm 0.1^{\mathrm{a}}$ & $1.2 \pm 0.1^{b}$ \\
\hline 72 & $83.0 \pm 0.8^{\mathrm{c}, \mathrm{d}}$ & $91.4 \pm 0.3^{\mathrm{a}}$ & $82.6 \pm 1.1^{\mathrm{a}, \mathrm{b}}$ & $52.5 \pm 3.2^{\mathrm{e}}$ & $1.2 \pm 0.2^{b}$ & $1.3 \pm 0.2^{\mathrm{a}}$ \\
\hline
\end{tabular}

${ }^{1}$ Unit: $\mathrm{mM} \mathrm{FeSO}_{4}$ eq. ${ }^{2}$ NFN, Non-fermented magnolia. ${ }^{3}$ FMPA, Magnolia fermented by P. acidilactici $\mathrm{KCCM}$ 11614. ${ }^{4}$ Values are means \pm SD of triplicate experiments. Data were grouped by Duncan's multiple range test.

DPPH is a stable radical and has been widely used for studying the free radical scavenging activity of several kinds of antioxidants [16]. The DPPH radical scavenging activity of fermented magnolia increased from $85.1 \%$ to $91.4 \%$ depending on the fermentation time, while those of the NFM (control) were not significantly different (Table 2 ).

In the $\beta$-carotene linoleate bleaching assay, free radical hydroperoxides generated by the auto-oxidation of linoleic acid can bleach $\beta$-carotene during incubation at $45-50{ }^{\circ} \mathrm{C}$, which is inhibited by antioxidants because of their hydroperoxide-neutralizing action [18]. Ibrahim et al. [19] reported that herbal teas fermented by lactic acid bacteria had significantly greater $(p<0.05)$ antioxidant activity $(70 \%-80 \%)$ compared with that of the control (freshly prepared herbal teas). In the present study, $72 \mathrm{~h}$ fermented magnolia decreased the $\beta$-carotene bleaching activity from $80.7 \%$ to $52.5 \%$ (Table 2). Hur et al. [20] showed that the $\beta$-carotene bleaching activity is affected by $\mathrm{pH}$ changes. This might have played a role in the current study as the $\mathrm{pH}$ decreased from 6.5 to around 3.3 during fermentation.

Using the FRAP method, the antioxidant activity of the fermented and NFM extract was estimated by the extracts' ability to reduce $\mathrm{Fe}^{3+}-\mathrm{TPTZ}$ to $\mathrm{Fe}^{2+}$-TPTZ [21]. The ferric ion-reducing activity of both 
extract samples was expressed as $\mathrm{mM} \mathrm{FeSO}_{4}$ eq. At a concentration of $36-25 \mathrm{mg} / \mathrm{solid} \mathrm{mL}$, the ferric reducing capacity was not significantly different between the fermented and NFM extract. However, after extraction with $70 \%$ ethanol and at a concentration of $0.125-2.0 \mathrm{mg} / \mathrm{solid} \mathrm{mL}$ to increase the concentration of effective compound in both extracts, the anti-oxidative activity as measured by the FRAP assay correlated with the solid concentration and was increased to $974.8 \pm 7.5 \mu \mathrm{M} \mathrm{FeSO}_{4}$ eq at $2.0 \mathrm{mg} / \mathrm{solid} \mathrm{mL}$ (Table 3).

Table 3. Ferric-reducing antioxidative capacity of Magnolia denudata extract ( $70 \%$ ethanol) fermented by $P$. acidilactici KCCM 11614.

\begin{tabular}{ccc}
\hline \multirow{2}{*}{ Conc. $(\mathbf{m g} / \mathbf{m L})$} & \multicolumn{2}{c}{ FRAP Assay $^{\mathbf{1}}$} \\
\cline { 2 - 3 } & NFM $^{2}$ & FMPA $^{3}$ \\
\hline 0.125 & - & $20.4 \pm 9.4^{4, \mathrm{~h}}$ \\
0.25 & - & $118.9 \pm 3.0^{\mathrm{f}}$ \\
0.5 & $83.2 \pm 1.8^{\mathrm{g}}$ & $226.2 \pm 5.7^{\mathrm{e}}$ \\
1.0 & $294.1 \pm 1.6^{\mathrm{d}}$ & $537.7 \pm 4.1^{\mathrm{c}}$ \\
2.0 & $641.5 \pm 6.5^{\mathrm{b}}$ & $974.8 \pm 7.5^{\mathrm{a}}$ \\
\hline
\end{tabular}

${ }^{1}$ Unit: $\mu \mathrm{M} \mathrm{FeSO}_{4}$ eq. ${ }^{2}$ NFM, Non-fermented magnolia. ${ }^{3}$ FMPA, Magnolia fermented by P. acidilactici KCCM 11614. ${ }^{4}$ Values are means \pm SD of triplicate experiments. Data were grouped by Duncan's multiple range test.

The stronger antioxidant activity of lacto-fermented $M$. denudata extract compared with that of the freshly prepared sample (control) was probably due to other factors including, for example, the inherent antioxidant activity of bacteria. Indeed, Yang et al. [22] reported that lactic acid bacteria such as Weissella confusa and Lactobacillus plantarum could have antioxidative effects. It is essential to apply different assays instead of depending on a single assay when determining the antioxidant activity as each method has different underlying mechanisms and methodological limitations. Therefore, the results obtained may be different depending on the analysis method used.

In general, many polyphenols including flavonoids exist as glycosides. Fermentation can cause bioconversion of glycosides. In addition, fermentation can improve antioxidative activity by increasing the release of flavonoids from plant-based foods, which can be a useful method for increasing the supply of natural antioxidative materials. For example, the fermentation-induced structural breakdown of the cell walls of plants may release bioactive compounds and/or induce the synthesis of various other compounds [23,24]. Ng et al. [25] also presented that fermentation increase the total phenolic contents in plant and the observed antioxidative activity may be due to the increase in the total phenolic compounds.

\subsection{In Vitro Determination of Anticanceric Activity}

Choi et al. [26] reported that Lactobacillus strains might constitute anticancer and antioxidative agents due to the presence of soluble polysaccharides in these strains. In the current study, the anticanceric activity of fermented $M$. denudata against four human cancer cell lines (AGS, LoVo, HeLa, and MCF-7) and one human control cell line (MRC-5, normal human lung tissue) was evaluated using the MTT assay. This assay is based on the cleavage of MTT's tetrazolium ring by the mitochondrial enzyme succinate dehydrogenase, converting MTT to insoluble, purple formazan. Therefore, the number of viable cells can be estimated directly by determining the amount of formazan formed [27]. 
In this study, both NFM and fermented $M$. denudata extract decreased the cell viability of the four different human cancer cell lines used as shown by the MTT assay (Table 4). The anticancer activity of fermented M. denudata extract, however, was higher than that of NFM, in particular against AGS, HeLa, and LoVo cells. AGS cells were the most sensitive to both extract treatments. As shown (in Table 4), the anticanceric activity of the $72 \mathrm{~h}$ fermented magnolia extract against AGS, LoVo, and MCF-7 cells was $85.0 \% \pm 2.8 \%, 88.4 \% \pm 1.3 \%$, and $92.0 \% \pm 0.6 \%$, respectively. Moreover, the anticancer effect was 1.29-1.36-fold higher than that of NFM. Interestingly, it seemed that HeLa cells were more resistant to the anticancer effect exerted by the $72 \mathrm{~h}$ fermented $M$. denudata extract than any of the other tested cancer cell lines were. On the other hand, the MRC-5 control cells were not significantly affected by fermented $M$. denudata compared with that by NFM $(p<0.05)$. Rutin and quercetin are the main flavonoids in magnolia [28] and are known to have anticancer as well as antioxidative effects [29]. Lignans constitute the main polyphenols found in magnolia [2] and have strong inhibitory effects on cell growth and can induce apoptosis in human cancer cell lines [30]. Hirano et al. [31] reported that lignans strongly suppressed the incorporation of $\left[{ }^{3} \mathrm{H}\right]$ thymidine, $\left[{ }^{3} \mathrm{H}\right]$ uridine, and $\left[{ }^{3} \mathrm{H}\right]$ leucine into HL-60 cancer cells. In addition, Simon et al. [32] reported that ROS and mitochondria play an important role in apoptosis induction under both physiologic and pathologic conditions. Therefore, the antioxidant activity of fermented magnolia could increase apoptosis of cancer cells. Several researchers have demonstrated that some flavonoids, such as quercetin and luteolin, have apoptotic activity against cancer cells $[33,34]$. The anti-cancer mechanisms underlying the flavonoids are various, including the induction of cell cycle arrest [35].

Overall, our results suggest that magnolia fermented by $P$. acidilactici can be used in functional foods developed in the food and pharmaceutical industry. However, further studies are needed to both understand the specific anticancer mechanisms underlying the effect of fermented magnolia, and to quantitatively analyze the major effective compounds to be used as potential end-products using high-performance liquid chromatography (HPLC).

Table 4. Anticanceric effects of fermented M. denudata extract on four different cancer cell lines.

\begin{tabular}{|c|c|c|c|c|c|c|c|c|c|c|}
\hline \multirow{3}{*}{$\begin{array}{c}\text { Time }^{1} \\
\text { (h) }\end{array}$} & \multicolumn{10}{|c|}{ Anticancer Activity (\%) } \\
\hline & \multicolumn{2}{|c|}{ AGS } & \multicolumn{2}{|c|}{ HeLa } & \multicolumn{2}{|c|}{ LoVo } & \multicolumn{2}{|c|}{ MCF-7 } & \multicolumn{2}{|c|}{ MRC-5 $^{2}$} \\
\hline & NFM $^{3}$ & MFPA $^{4}$ & NFM & MFPA & NFM & MFPA & NFM & MFPA & NFM & MFPA \\
\hline 0 & $61.3 \pm 9.9^{5, c}$ & $76.1 \pm 3.2^{b}$ & $62.4 \pm 8.4^{\mathrm{b}}$ & $78.1 \pm 3.2^{\mathrm{a}}$ & $72.8 \pm 4.1^{\mathrm{b}, \mathrm{c}}$ & $73.0 \pm 2.7^{b, c}$ & $64.4 \pm 0.9^{b, c, d}$ & $72.8 \pm 1.3^{d}$ & $82.1 \pm 5.1^{\mathrm{a}, \mathrm{b}}$ & $83.7 \pm 2.1^{\mathrm{a}}$ \\
\hline 12 & $59.0 \pm 6.3^{\mathrm{d}}$ & $80.8 \pm 2.7^{a, b}$ & $71.9 \pm 7.4^{\mathrm{a}, \mathrm{b}}$ & $82.6 \pm 7.1^{\mathrm{a}}$ & $73.9 \pm 5.1^{b, c}$ & $76.2 \pm 9.3^{b}$ & $66.4 \pm 7.1^{b, c, d}$ & $90.6 \pm 2.0^{b}$ & $81.6 \pm 1.1^{\mathrm{a}, \mathrm{b}}$ & $82.6 \pm 1.1^{\mathrm{a}, \mathrm{b}}$ \\
\hline 24 & $60.9 \pm 4.9^{\mathrm{d}}$ & $82.0 \pm 2.9^{\mathrm{a}, \mathrm{b}}$ & $76.3 \pm 3.9^{\mathrm{a}}$ & $74.7 \pm 7.4^{\mathrm{a}}$ & $78.8 \pm 5.4^{b}$ & $88.7 \pm 2.1^{\mathrm{a}}$ & $68.7 \pm 2.8^{\mathrm{b}, \mathrm{c}}$ & $90.7 \pm 1.0^{\mathrm{a}}$ & $83.3 \pm 2.7^{\mathrm{a}}$ & $84.6 \pm 3.0^{\mathrm{a}}$ \\
\hline 48 & $57.7 \pm 3.5^{\mathrm{c}, \mathrm{d}}$ & $83.7 \pm 0.3^{\mathrm{a}, \mathrm{b}}$ & $70.9 \pm 5.8^{\mathrm{a}, \mathrm{b}}$ & $75.2 \pm 6.2^{\mathrm{a}}$ & $63.8 \pm 1.8^{\mathrm{d}}$ & $87.1 \pm 0.3^{\mathrm{a}}$ & $62.5 \pm 2.6^{\mathrm{c}, \mathrm{d}}$ & $91.9 \pm 0.2^{\mathrm{a}}$ & $82.4 \pm 5.0^{\mathrm{a}, \mathrm{b}}$ & $83.6 \pm 2.0^{\mathrm{a}}$ \\
\hline 72 & $66.0 \pm 4.1^{\mathrm{c}, \mathrm{d}}$ & $85.0 \pm 2.8^{\mathrm{a}}$ & $71.2 \pm 3.2^{\mathrm{a}, \mathrm{b}}$ & $73.6 \pm 6.3^{a}$ & $66.1 \pm 4.0^{\mathrm{c}, \mathrm{d}}$ & $88.4 \pm 1.3^{\text {a }}$ & $67.5 \pm 8.5^{\mathrm{b}, \mathrm{c}, \mathrm{d}}$ & $92.0 \pm 0.6^{\mathrm{a}}$ & $80.4 \pm 0.4^{\mathrm{a}, \mathrm{b}}$ & $78.0 \pm 6.2^{\mathrm{a}, \mathrm{b}}$ \\
\hline
\end{tabular}




\section{Experimental Section}

\subsection{Strains and Chemicals}

P. acidilactici KCCM 11614 was obtained from the Korean Culture Center of Microorganisms (KCCM) in Seoul, Korea. The bacteria were cultured in MRS broth (Difco Laboratories, Detroit, MI, USA) at $37{ }^{\circ} \mathrm{C}$ for $12 \mathrm{~h}$ and were used to inoculate the extract samples to be fermented. Linoleic acid, $\beta$-carotene, $1,1-$ diphenyl-2-picrylhydrazy (DPPH), 2,4,6-tripyridyl-s-triazine (TPTZ), and 3-[4,5-dimethylthiazol-2-yl]2,5-diphenyltetrazolium bromide (MTT) were purchased from Sigma-Aldrich Co. (St. Louis, MO, USA).

\subsection{Cell lines and Culture Conditions}

Four cancer cell lines [AGS (human stomach adenocarcinoma), HeLa (human cervical adenocarcinoma), LoVo (human colon adenocarcinoma), and MCF-7 (human breast adenocarcinoma)] and one normal human lung tissue cell line (MRC-5) were purchased from the Korean Cell Line Bank (KCLB; Seoul National University, Seoul, Korea). The AGS, LoVo, and MCF-7 cell lines were incubated in RPMI 1640 medium (Gibco Laboratories, Grand Island, NY, USA) containing 10\% heat-inactivated fetal bovine serum (FBS; HyClone, Logan, UT, USA), penicillin (100 U/mL), and streptomycin $(100 \mu \mathrm{g} / \mathrm{mL})$. Both HeLa and MRC-5 cells were cultivated in minimum essential medium (MEM) containing 10\% FBS (HyClone), penicillin $(100 \mathrm{U} / \mathrm{mL})$, and streptomycin $(100 \mu \mathrm{g} / \mathrm{mL})$. All cells were cultured in a $\mathrm{CO}_{2}$ incubator (MCO-18AIC; Sanyo Electric Co., Ltd., Osaka, Japan) at $37{ }^{\circ} \mathrm{C}$ under a $5 \% \mathrm{CO}_{2} / 95 \%$ air atmosphere. Adherent cells in the logarithmic growth phase were harvested using $0.25 \%$ trypsin (Invitrogen Corp, Carlsbad, CA, USA). Cells were counted with a hemocytometer (Hausser Scientific, Horsham, PA, USA) and were subsequently seeded in new culture dishes and grown to $80 \%$ confluence prior to anticanceric activity testing.

\subsection{Fermentation of Magnolia}

Twenty grams of powdered $M$. denudata were mixed with $2.5 \mathrm{~g}$ of peptone $(0.5 \% \mathrm{w} / \mathrm{v})$ and $10 \mathrm{~g}$ of glucose $(2 \% \mathrm{w} / \mathrm{v})$ in $500 \mathrm{~mL}$ of distilled water, and the solution was sterilized at $121{ }^{\circ} \mathrm{C}$ for $15 \mathrm{~min}$. After cooling, the mixture was inoculated with $10 \mathrm{~mL}$ of the $P$. acidilactici strain $(2 \% v / v)$ and cultivated at $30{ }^{\circ} \mathrm{C}$ for $72 \mathrm{~h}$. For enumeration of cells, samples were diluted appropriately with $0.1 \%$ peptone solution and plated onto MRS agar (Difco Laboratories) media. After culturing, the fermented extract was filtered through a $0.45-\mu \mathrm{m}$ membrane filter and stored at $-20^{\circ} \mathrm{C}$ until use.

\subsection{Determination of the Total Polyphenol and Flavonoid Content}

The total polyphenol content (TPC) in the experimental solution was determined by adding $100 \mu \mathrm{L}$ of the resultant fermented mixture described under section 2.3 to $2 \mathrm{~mL}$ of a $2 \%$ aqueous sodium carbonate $\left(\mathrm{Na}_{2} \mathrm{CO}_{3}\right)$ solution. After a 3-min reaction, $100 \mu \mathrm{L}$ of $50 \%$ Folin-Ciocalteu's reagent was added to the mixture and the absorbance was measured at $750 \mathrm{~nm}$ with a spectrophotometer (2120UV; Optizen, Daejon, Korea) after a subsequent 30-min incubation period. The TPC was determined using a standard curve of gallic acid at $0,12.5,25,50$, and $100 \mu \mathrm{g} / \mathrm{mL}$. 
The total flavonoid content of the extract samples was calculated using an aluminum nitrate assay [36]. One hundred microliters of the fermented extract sample, $100 \mu \mathrm{L}$ of $10 \%$ ammonium nitrate $\left(\mathrm{NH}_{4} \mathrm{NO}_{3}\right)$, $100 \mu \mathrm{L}$ of $1.0 \mathrm{M}$ potassium acetate $\left(\mathrm{CH}_{3} \mathrm{COOK}\right)$, and $4.7 \mathrm{~mL}$ of $80 \%$ ethanol were mixed. The absorbance of the mixture after incubation at $25^{\circ} \mathrm{C}$ for 40 min was measured spectrophotometrically at $415 \mathrm{~nm}$. The total flavonoid content was calculated using the calibration curve of quercetin (Sigma-Aldrich Co.) and the results were expressed as mg of quercetin equivalents per $\mathrm{g}$ of solid sample (QE mg/g).

\subsection{Measurement of the Antioxidative Activity Using the DPPH Method}

Two hundred microliters of NFM and fermented extract were added to separate vials containing $1 \mathrm{~mL}$ of $100 \mu \mathrm{M}$ DPPH solution and were shaken. The reaction mixture was allowed to stand for $15 \mathrm{~min}$ after which its absorbance was measured at $517 \mathrm{~nm}$. The DPPH free radical scavenging activity of each sample was calculated as follows:

Radical scavenging activity $(\%)=\left[1-\left(\right.\right.$ Absorbance $_{\text {sample }} /$ Absorbance $\left.\left._{\text {control }}\right)\right] \times 100$

\subsection{Measurement of the Antioxidative Activity Using the $\beta$-Carotene Bleaching Activity Assay}

Twenty milligrams of $\beta$-carotene, $44 \mu \mathrm{L}$ of linoleic acid, and $200 \mu \mathrm{L}$ of Tween 80 were mixed in $10 \mathrm{~mL}$ of chloroform. Five milliliters of this mixture were vacuum-dried and re-solubilized with $100 \mathrm{~mL}$ distilled water for use as the $\beta$-carotene reagent in the assay. To determine the antioxidative activity of each extract sample, $0.5 \mathrm{~mL}$ of extract sample was reacted with $4.5 \mathrm{~mL}$ of the $\beta$-carotene reagent in a water bath at $50{ }^{\circ} \mathrm{C}$. During the incubation, the absorbance at $400 \mathrm{~nm}$ was determined at $2 \mathrm{~h}$ intervals. The antioxidative activity of the extract samples was calculated as follows:

Antioxidant activity $(\%)=($ Absorbance after reaction/Initial absorbance $) \times 100$

\subsection{Determination of Antioxidative Activity Using the Ferric Reducing Ability of Plasma Assay}

The ferric reducing ability of plasma (FRAP) assay working reagent was prepared by mixing $300 \mathrm{mM}$ of acetate buffer ( $\mathrm{pH} 3.6), 10 \mathrm{mM}$ of TPTZ solution, and $20 \mathrm{mM}$ of $\mathrm{FeCl}_{3} \cdot 6 \mathrm{H}_{2} \mathrm{O}$ in a 10:1:1 ratio immediately before use and by subsequent heating of the resultant mixture to $37^{\circ} \mathrm{C}$ [37]. Three hundred millimoles of acetate buffer were prepared by mixing $3.1 \mathrm{~g}$ of sodium acetate trihydrate $\left(\mathrm{C}_{2} \mathrm{H}_{3} \mathrm{NaO}_{2} \cdot 3 \mathrm{H}_{2} \mathrm{O}\right)$ with $16 \mathrm{~mL}$ of glacial acetic acid, adjusting the total, final volume to $1 \mathrm{~L}$ with distilled water. The TPTZ solution was prepared as a solution of $10 \mathrm{mM} \mathrm{TPTZ} \mathrm{in} 40 \mathrm{mM} \mathrm{HCl}$. One hundred microliters of extract sample were mixed with $1.9 \mathrm{~mL}$ of the working reagents, the resultant mixture was incubated at $25{ }^{\circ} \mathrm{C}$ in the dark for $30 \mathrm{~min}$, and the absorbance was read at $593 \mathrm{~nm}$. A standard curve ranging from $50 \mu \mathrm{M}$ to $1.5 \mathrm{mM}$ of $\mathrm{FeSO}_{4}$ was prepared for the quantitative determination of $\mathrm{FeSO}_{4}$ as $\mathrm{mM} \mathrm{Fe}^{2+}$ and $\mathrm{FeSO}_{4}$ equivalents (eq) produced in the samples.

\subsection{In Vitro Determination of Anticanceric Activity}

The tetrazolium-based colorimetric assay (MTT test) was used for the determination of anticancer activity [38]. One-hundred microliters of the respective cell suspensions were transferred to 96-well microplates. After one day incubation, $100 \mu \mathrm{L}$ of the extract samples were added to the culture media 
and the cells were incubated at $37^{\circ} \mathrm{C}$ for another $44 \mathrm{~h}$ after which the media were discarded and $100 \mu \mathrm{L}$ of MTT $(2.5 \mathrm{mg} / \mathrm{mL}$ in phosphate-buffered saline (PBS)) reagent was added to the microplate wells. Following a subsequent incubation for $4 \mathrm{~h}$, the supernatant was discarded and $100 \mu \mathrm{L}$ of dimethyl sulfoxide (DMSO) was added to each well to dissolve the colored formazan crystals generated by the reaction of the cells with MTT. The absorbance of all samples was measured at $570 \mathrm{~nm}$ with a microplate reader (EL311; Bio-Teck Instrument Inc., Seoul, Korea). All experiments were performed in triplicate and the extract samples' anticanceric activity was calculated as follows:

$$
\text { Anticanceric activity }(\%)=\left[1-\left(\text { Absorbance }_{\text {sample }} / \text { Absorbance }_{\text {control }}\right)\right] \times 100
$$

\subsection{Statistical Analysis}

Each experiment was performed in triplicate. Analysis of variance (ANOVA) was performed using the SPSS software, version 18 (IBM; Chicago, IL, USA). Differences were considered significant at $p<0.05$.

\section{Acknowledgments}

This research was supported by Ministry of Agriculture, Food and Rural Affairs (Korea, 314020-2); the 2014 High Value-Added Food Industry Professional Human Resources Development Project, Ministry for Food, Agriculture, Forestry and Fisheries (Korea, 614102-2); and by a grant from the Priority Research Centers Program through the National Research Foundation of Korea funded by Ministry of Education, Science and Technology (2009-0093824).

\section{Author Contributions}

E.-H.P. and H.-S.K. designed and performed research; S.J.E. contributed experimental materials; K.-T.K. wrote the research paper; H.-D.P., corresponding author, designed and advised the research.

\section{Conflicts of Interest}

The authors declare no conflict of interest.

\section{References}

1. Wang, R.; Jia, H.; Wang, J.; Ahang, Z. Flowering and pollination patterns of Magnolia denudata with emphasis on anatomical changes in ovule and seed development. Flora 2010, 205, 259-265.

2. Seo, Y. Antioxidant activity of chemical constituents from the flower buds of Magnolia denudata. Biotechnol. Bioprocess Eng. 2010, 15, 400-406.

3. Noshita, T.; Kiyot, H.; Kidachi, Y.; Ryoyama, K.; Funayama, S.; Hanada, K.; Murayama, T. New cytotoxic phenolic derivatives from matured fruits of Magnolia denudata. Biosci. Biotechnol. Biochem. 2009, 73, 726-728.

4. Zhang, Z.; Lv, G.; Pan, H.; Fan, L.; Soccol, C.R.; Pandey, A. Production of powerful antioxidant supplements via solid-state fermentation of wheat (Triticum aestivum Linn.) by Cordyceps militaris. Food Technol. Biotechnol. 2012, 50, 32-39. 
5. Torino, M.I.; Limon, R.I.; Martinez-Villaluenga, C.; Makinen, S.; Pihlanto, A.; Vidal-Valverde, C.; Frias, J. Antioxidant and antihypertensive properties of liquid and solid state fermented lentils. Food Chem. 2013, 136, 1030-1037.

6. Jo, M.N.; Jung, J.E.; Lee, J.H.; Park, S.H.; Yoon, H.J.; Kim, K.T.; Paik, H.D. Cytotoxicity of the white ginseng extract and red ginseng extract treated with partially purified $\beta$-glucosidase from Aspergillus usamii KCTC 6954. Food Sci. Biotechnol. 2014, 23, 215-219.

7. Yoon, H.J.; Lee, K.A.; Lee, J.H.; Jin, H.J.; Kim, H.J.; Kim, K.T.; Paik, H.D. Effect of fermentation by Bacillus subtilis on antioxidant and cytotoxic activities of black rice bran. Int. J. Food Sci. Technol. 2015, 50, 612-618.

8. Aydemir, O.; Harth, H.; Weckx, S.; Dervisoglu, M.; de Vuyst, L. Microbial communities involved in Kasar cheese ripening. Food Microbiol. 2015, 46, 587-595.

9. Kaur, B.; Chakraborty, D.; Kumar, B. Metabolic engineering of Pediococcus acidilactici BD16 for production of vanillin through ferulic acid catabolic pathway and process optimization using response surface methodology. Appl. Microbiol. Biotechnol. 2014, 98, 8539-8551.

10. Michlmayr, H.; Brandes, W.; Eder, R.; Schümann, C.; Del Hierro, A.M.; Kulbe, K.D. Characterization of two distinct glycosyl hydrolase family $78 \alpha$-1-rhamnosidases from Pediococcus acidilactici. Appl. Environ. Microbiol. 2011, 77, 6524-6530.

11. Reuter, S.; Gupta, S.C.; Chaturvedi, M.M.; Aggarwal, B.B. Oxidative stress, inflammation, and cancer: How are they linked? Free Radic. Biol. Med. 2010, 49, 1603-1616.

12. Poyton, R.O.; Ball, K.A.; Castello, P.R. Mitochondrial generation of free radicals and hypoxic signaling. Trends Endocrinol. Metab. 2009, 20, 332-340.

13. Durackova, Z. Some current insights into oxidative stress. Physiol. Res. 2010, 59, 459-469.

14. Schraufstatter, I.; Hyslop, P.A.; Jackson, J.H.; Cochrane, C.G. Oxidant-induced DNA damage of target cells. J. Clin. Investig. 1988, 82, 1040-1050.

15. Mihajlovic, L.; Radosavljevic, J.; Burazer, L.; Smiljanic, K.; Velickovic, T.C. Composition of polyphenol and polyamide compounds in common ragweed (Ambrosia artemisiifolia L.) pollen and sub-pollen particles. Phytochemistry 2015, 109, 125-132.

16. Dong, J.; Zhao, L.; Cai, L.; Fang, H.; Chen, X.; Ding, Z. Antioxidant activities and phenolics of fermented Bletilla formosana with eight plant pathogen fungi. J. Biosci. Bioeng. 2014, 118, 396-399.

17. Duenas, M.; Fernandez, D.; Hernandez, T.; Estrella, I.; Munoz, R. Bioactive phenolic compounds of cowpeas (Vigna sinensis L.) Modifications by fermentation with natural microflora and with Lactobacillus plantarum ATCC14917. J. Sci. Food Agric. 2005, 85, 297-304.

18. Othman, A.; Ismail, A.; Abdul Ghani, N.; Adenan, I. Antioxidant capacity and phenolic content of cocoa beans. Food Chem. 2007, 100, 1523-1530.

19. Ibrahim, N.A.; Mustafa, S.; Ismail, A. Effect of lactic fermentation on the antioxidant capacity of Malaysian herbal teas. Int. Food Res. J. 2014, 21, 1483-1488.

20. Hur, S.J.; Lee, S.Y.; Kim, Y.C.; Choi, I.; Kim, G.B. Effect of fermentation on the antioxidant activity in plant-based foods. Food Chem. 2014, 160, 346-356.

21. Pulido, R.; Bravo, L.; Saura-Calixto, F. Antioxidant activity of dietary polyphenols as determined by a modified ferric reducing/antioxidant power assay. J. Agric. Food Chem. 2000, 48, 3396-3402. 
22. Yang, J.; Ji, Y.; Park, H.; Lee, J.; Park, S.; Yeo, S.; Shin, H.; Holzapfel, W.H. Selection of functional lactic acid bacteria as starter cultures for the fermentation of Korean leek (Allium tuberosum Rottler ex Sprengel.). Int. J. Food Microbiol. 2014, 191, 164-171.

23. Katina, K.; Laitila, A.; Juvonen, R.; Liukkonen, K.H.; Kariluoto, S.; Piironen, V.; Landberg, R.; Åman, P.; Poutanen, K. Bran fermentation as a means to enhance technological properties and bioactivity of rye. Food Microbiol. 2007, 24, 175-186.

24. Đorđević, T.M.; Šiler-Marinković, S.S.; Dimitrijević-Branković, S.I. Effect of fermentation on antioxidant properties of some cereals and pseudo cereals. Food Chem. 2010, 119, 957-963.

25. Ng, C.C.; Wang, C.Y.; Wang, Y.P.; Tzeng, W.S.; Shyu, Y.T. Lactic acid bacterial fermentation on the production of functional antioxidant herbal Anoectochilus formosanus Hayata. J. Biosci. Bioeng. 2011, 111, 289-293.

26. Choi, SS.; Kim, Y.; Han, K.S.; You, S. Effects of Lactobacillus strains on cancer cell proliferation and oxidative stress in vitro. Lett. Appl. Microbiol. 2006, 42, 452-458.

27. Lee, J.Y.; Hwang, W.I.; Lim, S.T. Antioxidant and anticancer activities of organic extracts from Platycodon grandiflorum A. De Candolle roots. J. Ethnopharmacol. 2004, 93, 409-415.

28. Kawahara, T.; Tomono, T.; Hamauzu, Y.; Tanaka, K.; Yasui, H. Inhibitory effect of a hot-water extract of leaves of Japanese big-leaf magnolia (Magnolia obovata) on rotavirus-induced diarrhea in mouse pups. Evid-Based Complement. Altern. Med. 2014, 2014, doi:10.1155/2014/365831.

29. Caia, Y.; Luo, Q.; Sun, M.; Corke, H. Antioxidant activity and phenolic compounds of 112 traditional Chinese medicinal plants associated with anticancer. Life Sci. 2004, 74, 2157-2184.

30. Yu, S.; Lv, J.J.; Zhao, J.Q.; Li, Y.; Wang, D.; Yang, C.R.; Xu, M.; Zhang, Y.J. New cytotoxic lignan glycosides from Phyllanthus glaucus. Nat. Prod. Res. 2015, doi:10.1080/14786419.2015.1023198.

31. Hirano, T.; Gotoh, M.; Oka, K. Natural flavonoids and lignans are potent cytostatic agents against human leukemic HL-60 cells. Life Sci. 1994, 55, 1061-1069.

32. Simon, H.U.; Haj-Yehia, A.; Levi-Schaffer, F. Role of reactive oxygen species (ROS) in apoptosis induction. Apoptosis 2000, 5, 415-418.

33. Vijayababu, M.R.; Kanagaraj, P.; Arunkumar, A.; Ilangvan, R.; Dharmarajan, A.; Arunakaran, J. Quercetin induces p53-independent apoptosis in human prostate cancer cells by modulating Bcl-2-related proteins: A possible mediation by IGFBP-3. Oncol. Res. 2006, 16, 67-74.

34. Lim, Y.; Jeong, T.; Tyner, A.L.; Park, J.H. Induction of cell cycle arrest and apoptosis in HT-29 human colon cancer cells by the dietary compounds luteolin. Am. J. Physiol. Gastrointest. Liver Physiol. 2007, 292, 66-75.

35. Chang, H.; Mi, M.; Ling, W.; Zhu, J.; Zhang, Q.; Wei, N.; Zhou, Y.; Tang, Y.; Yuan, J. Structurally related cytotoxic effects of flavonoids on human cancer cells in vitro. Arch. Pharm. Res. 2008, 31, $1137-1144$.

36. Moreno, M.I.N.; Isla, M.I.; Sampietro, A.R.; Vattuone, M.A. Comparison of the free radical-scavenging activity of propolis from several regions of Argentina. J. Ethnopharmacol. 2000, 71, 109-114.

37. Benzie, I.F.F.; Strain, J.J. The ferric reducing ability of plasma (FRAP) as a measure of "antioxidant power": The FRAP assay. Anal. Biochem. 1996, 239, 70-76. 
38. Wang, X.; Wei, Y.; Yuan, S.; Liu, G.; Zhang, Y.L.; Wang, W. Potential anticancer activity of litchi fruit pericarp extract against hepatocellular carcinoma in vitro and in vivo. Cancer Lett. 2006, 239, 144-150.

Sample Availability: Not available.

(C) 2015 by the authors; licensee MDPI, Basel, Switzerland. This article is an open access article distributed under the terms and conditions of the Creative Commons Attribution license (http://creativecommons.org/licenses/by/4.0/). 